Peer Reviewed - International Journal

Vol-4, Issue-2, 2020 (IJEBAR)

E-ISSN: 2614-1280 P-ISSN 2622-4771

https://jurnal.stie-aas.ac.id/index.php/IJEBAR

\title{
INFLUENCE OF ORGANIZATIONAL LEADERSHIP AND COMMITMENT AND WORK ABILITY TO MOTIVATION AND PERFORMANCE EMPLOYEE'S EMPLOYEE, EDUCATION AND REGIONAL TRAINING IN THE CITY OF SAMARINDA
}

\author{
Nurhikmah1, Rusdiah Iskandar2, Gusti Noorlitaria Achmad3 \\ 1,2,3Faculty of Economics and Business Mulawarman University \\ Email:nurhikmahn244@gmail.com,rusdiah.iskandar@feb.unmul.ac.id \\ gusti.noorlitaria.achmad@feb.unmul.ac.id
}

\begin{abstract}
:
Data analysis method that will be used is Stuctural Equation Modeling analysis. In this study data analysis using PLS approach. PLS is a model of SEM equations based on components or variants. Population in this research is all employees of Agency Personnel, Education and Training Area of Samarinda City. The results showed that; Leadership gives a negative influence on motivation, leadership does not have a significant effect on motivation, Leadership gives a positive influence on performance, leadership gives no significant effect on performance, organizational commitment has a positive influence on motivation, organizational commitment does not have a significant effect on motivation, organizational commitment has a negative influence on performance, organizational commitment does not have a significant effect on performance, work ability has a positive influence on motivation, work ability provides significant influence on motivation, work ability gives a positive influence on performance, work ability provides insignificant influence on performance, motivation has a positive influence on performance, motivation has a significant influence on the performance.

Keywords: Leadership, Organizational Commitment, work ability, motivation and performance
\end{abstract}

\section{Introduction}

This study focused on employees of the Samarinda City Regional Personnel, Education and Training Agency. High employee performance is a demand by the organization, with the expectation that overall organizational productivity will increase. Employees are required to be able to complete their duties and responsibilities effectively and efficiently. The performance of Samarinda City Regional Personnel, Education and Training Agency employees can be measured through the effective and efficient completion of their duties and carrying out their roles and functions, and these are all linearly related and positively related to organizational success. Associated with the actual situation on the ground, the performance of employees at the Samarinda City Regional Personnel, Education and Training Agency is still not in accordance with the ideal demands of the organization, which can be seen from the still many complaints about employee performance, both from internal (dissatisfaction among colleagues) and from external (complaints and criticisms of employees served, superiors and even the mass media).

Achievement of optimal performance at the Samarinda City Regional Staffing, Education and Training Agency is expected to be achieved by employees through their knowledge of organizational commitment and motivation built by employees together with the organization, with leadership in line with organizational goals and employee character that refers to improvement as well as the work ability of employees in carrying out their responsibilities, so that the Regional Employment, Education and Training Agency of Samarinda City is able to 


\section{International Journal of Economics, Business and Accounting Research (IJEBAR) \\ Peer Reviewed - International Journal \\ Vol-4, Issue-2, 2020 (IJEBAR) \\ E-ISSN: 2614-1280 P-ISSN 2622-4771 \\ https://jurnal.stie-aas.ac.id/index.php/IJEBAR}

achieve the targeted goals through optimizing employee performance that has not been achieved in reality.

There are negative factors that reduce the performance of employees at the Samarinda City Regional Personnel, Education and Training Agency, including the lack of application of rewards and punishments within the organization, the weaker sense of engagement in the organization, lack of timeliness in completing work, and the lack of examples of leaders or colleagues which can be a role model in the world of work. As an organization engaged in the service sector that is demanded that everything, including job targets, can be carried out on time. Employees of the Samarinda City Regional Civil Service, Education and Training Agency have not optimally implemented this, which can be seen from the lack of employee attention to the responsibilities given, as well as the habit of delaying work which makes it less than maximizing its capabilities. All of that is the cause of declining employee performance.

\section{Literature Review}

\section{The effect of leadership on motivation}

Leadership influences employee work motivation, this is supported by previous research conducted by Naile, \& Selesho (2014), Smat (2005), stating that leadership influences employee work motivation.

Leadership and motivation are important elements that must be possessed not only by management in business, but also employees who are part of the organization. Leading is the ability to influence others in the group. Being a good leader requires an understanding of what motivates others. Success or failure of an organization is determined by leadership, because the leader is responsible for the failure of the implementation of work, on the contrary success in leading an organization is the success of someone influencing others to move or carry out his vision, besides that there is good coordination or cooperation between leaders and subordinates. Dessler (2010: 143) states that leadership has a close relationship with motivation because the success of a leader in moving others to achieve the goals that have been determined is very dependent on authority, besides how to create motivation in employees, colleagues and leaders themselves.

H1: Leadership has a direct and significant effect on employee motivation

\section{The effect of organizational commitment on motivation}

Organizational commitment affects employee work motivation, this is supported by previous research conducted by Noerhayati, (2011) stating that organizational commitment influences employee work motivation.

In the process of organizational commitment, they are building values based on commonalities. Every member of the organization has the same opportunity, for example for promotion, the basis used for promotion is the ability, skills, interests, motivation, performance without discrimination, thus motivation has an important relationship with organizational commitment, motivation is one aspect of the commitment process organization. In organizational psychology literature, organizational commitment and motivation usually develop independently to some extent. According to Meyer in Robbins (2007: 89) said that commitment is one of the important components of motivation, Meyer believes that commitment is considered as an important part of motivation.

H2: Organizational commitment has a direct and significant effect on employee motivation

\section{The effect of work ability on motivation}

Work ability affects employee work motivation, this is supported by previous research conducted by Runi, et al. (2017), Nasir, et al. (2017), states that work ability influences employee work motivation. 


\section{International Journal of Economics, Business and Accounting Research (IJEBAR) \\ Peer Reviewed - International Journal \\ Vol-4, Issue-2, 2020 (IJEBAR) \\ E-ISSN: 2614-1280 P-ISSN 2622-4771 \\ https://jurnal.stie-aas.ac.id/index.php/IJEBAR}

Motivation is an activity that results in, channeling and maintaining human behavior. Motivation is an important subject, because through motivation a work ability of employees will be created. Leaders need to understand the behavior of certain people in order to influence it to work to fit what the organization wants. According to Herzberg (2009: 7) one of the factors that can increase employee motivation is the ability possessed by employees. According to Dessler (2010: 214) ability will determine how a person can do work, talent will play a role in helping to carry out work if there is conformity to the type of work, as well as perceptions, self-concepts, values, interests, emotions, needs and personality. All that will affect the motivation (motivation) of someone in carrying out their work. Thus the study of performance also requires a discussion of motivation, because a person's behavior in carrying out work can not be separated from the impetus behind it.

H3: Work ability has a direct and significant effect on employee motivation\}

\section{The influence of leadership on performance}

Leadership affects employee performance, this is supported by previous research conducted by Hurduzeu (2015), Melmambessy, (2008), Roslinawati, (2011), Runi, et al. (2017), Harwiki (2013), states that leadership influences employee performance.

According to Challagalla \& Shervani (2006: 96) the role of leadership is the leader (manager) oriented towards increasing ability to focus on developing employee skills to improve the quality of employee performance. These findings suggest that leaders (managers) must carefully match the applicable controls with the desired results. Overall, these results indicate that information and the effect of reinforcement are variable, which suggests the need to differentiate between the information available and the actual reinforcement assumed to employees. They also show that activity control and skill control have different effects and illustrate the sharp distinction between the two types of behavioral control. Furthermore, according to Challagalla \& Shervani (2006: 101) the role of leadership control (supervisor) has a direct and indirect positive effect on employee performance.

H4: Leadership has a direct and significant effect on employee performance

\section{Effect of organizational commitment on performance}

Organizational commitment influences employee performance, this is supported by previous research conducted by Noerhayati, (2011), Roslinawati, (2011), Runi, et al. (2017), states that organizational commitment influences employee performance.

Organizational commitment is identification (trust in organizational values), involvement (willingness to do their best for the sake of the organization) and loyalty (the desire to remain a member of the organization concerned) expressed by an employee of the organization. Furthermore Steers stated that organizational commitment is a condition where employees are very interested in the goals, values and goals of the organization. Commitment to the organization means more than formal membership, because it includes an attitude of liking the organization and a willingness to strive for a high level of effort for the interests of the organization for the achievement of objectives. Organizational commitment has an important role in shaping the character of the organization, through organizational commitment employees will have competitiveness that is measured through the performance that has been achieved. According to Robbins (2007: 89) found the influence of organizational commitment to performance, commitment is seen as a value orientation to the organization that shows individuals are very concerned about and prioritize their work and organization. Individuals will try to give all their business in order to help the organization achieve its goals.

H5: Organizational commitment has a direct and significant effect on employee performance 


\section{International Journal of Economics, Business and Accounting Research (IJEBAR) \\ Peer Reviewed - International Journal \\ Vol-4, Issue-2, 2020 (IJEBAR) \\ E-ISSN: 2614-1280 P-ISSN 2622-4771 \\ https://jurnal.stie-aas.ac.id/index.php/IJEBAR}

\section{Effect of work ability on performance}

Work ability affects employee performance, this is supported by previous research conducted by Nasir, et al. (2017), Runi, et al. (2017) states that work ability influences employee performance.

Ability is a key requirement in performance. The ability possessed by someone to carry out the work given to him well (Wibowo, 2010: 104). According Wiryawan (2009: 7) states that ability is an internal factor of employees that can directly influence employee performance. According to Hatta (2011: 18) states that an important factor in the success of an organization's performance is the existence of employees who have the ability to work.

H6: Work ability has a direct and significant effect on employee performance.

\section{The effect of motivation on performance}

Work motivation affects employee performance, this is supported by previous research conducted by Nasir, et al. (2017), Harwiki (2013), Runi, et al. (2017), Roslinawati, (2011), Noerhayati, (2011), stated that work motivation influences employee performance.

Motivation is an expertise in directing employees to organizational goals so they want to work and try so that the desires of employees and organizational goals can be achieved. Someone's motivation to do a job because of a necessity of life that must be met. This need can be in the form of economic needs, namely to obtain money, while non-economic needs can be interpreted as the need to obtain more advanced rewards and desires. With all these needs, a person is required to be more active and active in working, to achieve this it requires motivation to do work, because it can encourage someone to work and always eager to continue their business. Therefore, if employees who have high work motivation usually have high performance as well. Rivai (2004: 43) shows that the stronger work motivation, employee performance will be higher. This means that any increase in employee motivation will provide a significant increase in improving employee performance in carrying out their work.

H7: Motivation has a direct and significant effect on employee performance

\section{Research Method}

In this study involving all Civil Servants in the Environment Agency, Education and Training District of Samarinda City. The sampling technique in this study is nonprobability sampling. The greater the number of samples, the better. The sample of this study was employees of the Samarinda City Regional Personnel, Education and Training Agency. For sampling, the author uses population research techniques or census methods in which the entire population is sampled with as many as 56 Civil Servants in the Samarinda City Regional Personnel, Education and Training Agency.

Analysis of the data used by the author is the Structural Equation Model (SEM). Hypothesis testing is done by multivariate analysis carried out through the SmartPLS program. Data analysis through partial Least Square (PLS) is done through two stages, namely: a) Assessing the outer model or measurement model, b) Assessing the inner model or structural model.

\section{Results and Discussion}

\section{Results}

Through the original sample estimate indicators that provide the dominant influence on each exogenous and endogenous variables in the study with the following information:

1) The dominant indicator that gives influence to leadership is indicator X1.2 with a coefficient value of 0.970 .

2) The dominant indicator that gives effect to organizational commitment is the indicator $X 2.1$ with a coefficient value of 0.929 . 
International Journal of Economics, Business and Accounting Research (IJEBAR)

Peer Reviewed - International Journal

Vol-4, Issue-2, 2020 (IJEBAR)

E-ISSN: 2614-1280 P-ISSN 2622-4771

https://jurnal.stie-aas.ac.id/index.php/IJEBAR

3) The dominant indicator that gives effect to work ability is indicator X3.3 with a coefficient value of 0.811 .

4) The dominant indicator that gives effect to work motivation is indicator Y1.3 with a coefficient value of 0.816 .

5) The dominant indicator that gives effect to performance is the indicator Y2.3 with a coefficient value of 0.793 .

Examination of the model can be seen from the value of R2 (R-square). This means that the model can explain phenomena or variations in work motivation can be explained by leadership variables, organizational commitment and work ability by 57.90 percent $(0.579 \times 100 \%)$ while the rest is explained by variations of other variables outside of the research model by 42.10 percent $(100 \%-57.90 \%)$. The phenomenon or variation in performance can be explained by leadership variables, organizational commitment, work ability and work motivation by 55.80 percent $(0.558 \times 100 \%)$ while the rest is explained by other variable variations outside of the research model by 44.20 percent $(100 \%$ - 55 , 80\%). The smartPLS program is done by t-test on each track. The test results can be seen in the table below:

Table: Results For Inner Weights

\begin{tabular}{|l|c|c|c|c|c|}
\hline \multicolumn{1}{|c|}{ Variabel } & $\begin{array}{c}\text { Original } \\
\text { sample }\end{array}$ & $\begin{array}{c}\text { Mean of } \\
\text { subsamples }\end{array}$ & $\begin{array}{c}\text { Standard } \\
\text { deviation }\end{array}$ & $\begin{array}{c}\text { T- } \\
\text { Statistik }\end{array}$ & P-Values \\
\hline $\begin{array}{l}\text { Leadership } \rightarrow \\
\text { Motivation }\end{array}$ & $-0,006$ & 0,001 & 0,101 & 0,059 & 0,953 \\
\hline $\begin{array}{l}\text { Leadership } \rightarrow \\
\text { Performance }\end{array}$ & 0,065 & 0,078 & 0,107 & 0,609 & 0,543 \\
\hline $\begin{array}{l}\text { Organizational } \\
\text { commitment } \\
\text { Motivation }\end{array}$ & 0,157 & 0,162 & 0,090 & 1,737 & 0,080 \\
\hline $\begin{array}{l}\text { Organizational } \\
\text { commitment } \rightarrow \\
\text { Performance }\end{array}$ & $-0,047$ & $-0,034$ & 0,130 & 0,362 & 0,717 \\
\hline $\begin{array}{l}\text { Work ability } \rightarrow \\
\text { Motivation }\end{array}$ & 0,706 & 0,714 & 0,084 & 8,398 & 0,000 \\
\hline $\begin{array}{l}\text { Work ability } \rightarrow \\
\text { Performance }\end{array}$ & 0,045 & 0,052 & 0,157 & 0,284 & 0,777 \\
\hline $\begin{array}{l}\text { Motivation } \rightarrow \\
\text { Performance }\end{array}$ & 0,704 & 0,698 & 0,141 & 5,014 & 0,000 \\
\hline
\end{tabular}

\section{Discussion}

Based on the table, it can be seen the positive influence and the level of significance of each variable, if T-Statistic> 1.96 means that exogenous variables have a significant influence on endogenous variables and if T-Statistic <1.96, exogenous variables give insignificant influence on endogenous variables with an explanation as following:

1) Leadership gives a negative influence on motivation with a value of -0.006 , it can also be seen that leadership gives no significant effect on motivation because it has a t-statistic $(0.059<1.96)$, so the results of this study are not in line with the hypothesis that leadership has a positive effect and significant on motivation.

2) Leadership has a positive influence on performance with a value of 0.065 , it can also be seen that leadership has no significant effect on performance because it has a t-statistic $(0.609<1.96)$, so the results of this study are not in line with the hypothesis that leadership has a positive and significant effect on performance.

3) Organizational commitment gives a positive influence on motivation with a value of 0.157 , it can also be seen that organizational commitment does not have a significant effect on 


\section{International Journal of Economics, Business and Accounting Research (IJEBAR) \\ Peer Reviewed - International Journal \\ Vol-4, Issue-2, 2020 (IJEBAR) \\ E-ISSN: 2614-1280 P-ISSN 2622-4771 \\ https://jurnal.stie-aas.ac.id/index.php/IJEBAR}

motivation because it has a t-statistic $(1.737<1.96)$, so the results of this study are not in line with the hypothesis that states organizational commitment influences positive and significant to motivation.

4) Organizational commitment gives a negative influence on performance with a value of 0.047 , it can also be seen that organizational commitment does not have a significant effect on performance because it has a t-statistic $(0.362<1.96)$, so the results of this study are not in line with the hypothesis stating organizational commitment a positive and significant effect on performance.

5) Work ability has a positive influence on motivation with a value of 0.706 , it can also be seen that work ability has a significant effect on motivation because it has a t-statistic (8.339> 1.96), so the results of this study are in line with the hypothesis that work ability has a positive effect and significant on motivation.

6) Work ability gives a positive influence on performance with a value of 0.045 , it can also be seen that work ability gives no significant effect on performance because it has a t-statistic $(0.284<1.96)$, so the results of this study are not in line with the hypothesis that the work ability has an effect positive and significant impact on performance.

7) Motivation gives a positive influence on performance with a value of 0.704 , it can also be seen that motivation has a significant effect on performance because it has a t-statistic (5.014> 1.96), so the results of this study are in line with the hypothesis that motivation has a positive and significant effect on performance.

\section{Conclusions}

Based on the results of the analysis and discussion it can be concluded as follows:

1) Leadership has a negative influence on motivation, it can also be seen that leadership has an insignificant influence on the motivation of Samarinda City's Civil Service, Education and Training Employees.

2) Leadership has a positive influence on performance, it can also be seen that leadership has an insignificant influence on the performance of Samarinda City's Civil Service, Education and Training Employees.

3) Organizational commitment gives a positive influence on motivation, it can also be seen that organizational commitment does not have a significant effect on the motivation of Samarinda City Staffing, Education and Training Employees.

4) Organizational commitment gives a negative influence on performance, it can also be seen that organizational commitment does not have a significant effect on the performance of Employees of Samarinda City's Civil Service, Education and Training Agency.

5) Work ability has a positive influence on motivation, it can also be seen that work ability has a significant influence on the motivation of Samarinda City Staffing, Education and Training Employees.

6) Work ability has a positive influence on performance, it can also be seen that work ability has insignificant effect on the performance of Employees of Samarinda City's Civil Service, Education and Training Agency.

7) Motivation provides a positive influence on performance, it can also be seen that motivation has a significant influence on the performance of Employees in the Samarinda City Employee, Education and Training Agency.

Based on the conclusions above, the suggestions in this study are as follows:

1) From the results of the study note that the leadership variable does not significantly influence motivation, therefore, there needs to be a leadership approach in providing motivation to employees to improve performance, leadership variables in an organization are very important because leaders have the ability to influence others (subordinates) so arises work enthusiasm for achieving the goals or objectives of the organization. Not just influencing 


\section{International Journal of Economics, Business and Accounting Research (IJEBAR) \\ Peer Reviewed - International Journal \\ Vol-4, Issue-2, 2020 (IJEBAR) \\ E-ISSN: 2614-1280 P-ISSN 2622-4771 \\ https://jurnal.stie-aas.ac.id/index.php/IJEBAR}

subordinates, but at the same time fostering participation and concern for subordinates to the organization where he works.

2) Motivation and leadership variables have no less important role in terms of improving employee performance so that this needs to be considered and maintained by the relevant organizations namely the Employment Agency, Education and Training City of Samarinda through meeting the needs of employees that become dimensions for motivation variables and Samarinda City Regional Personnel, Education and Training Agency employee leadership.

3) Based on the observations of researchers in the field there is still a lack of supervision conducted by the leadership of subordinates on the tasks assigned as employee responsibilities due to the location that are far apart because of the wide coverage area so that the leadership has difficulty making observations making unfinished work in accordance with the provisions. Therefore, supervision is needed by the leadership by delegating supervisory tasks to those who are able to supervise so that employee performance increases followed by increased motivation given by the organization to employees of the Samarinda City Regional Staffing, Education and Training Agency.

\section{References}

Alkahtani, Ali Hussein, 2016, The Influence of Leadership Styles on Organizational Commitment: The Moderating Effect of Emotional Intelligence. Business and Management Studies, Vol. 2, No. 1; March 2016, ISSN 2374-5916 E-ISSN 23745924.

Alwi, Syarafudin, 2001, Human Resources Management Competitive Advantage Strategy, BPFE, Yogyakarta.

Arep and Tanjung, 2003, Motivation Management, Publisher of PT Grasindo, Jakarta.

Azhar, Fachri. 2009. Relationship Between Leadership Style and Employee Motivation in Organizations. Thesis: Department of Communication Science and Community Development Faculty of Human Ecology. ITB. Bogor.

Bernardin and Russel, 2006, Smart Managers, Various Contemporary Views, Agus Maulana Interpreting. Publisher Binarupa Aksara, Jakarta.

Challagalla, N. Goutham \& Shervani, A. Tasadduq. 2006. "Dimensional and Type of Supervisory Control: Effect on Sallesperson Performance and Satisfaction". Journal Marketing. Vol. 60. January.

Daft, Richard L. 2002. Management. Fifth Edition Volume One. Jakarta: Erlangga.

Dessler, Gary. 2010. Human Resources Management, Eight Edition, Prentice Hall, New Jersey.

Devi, Eva K. D. 2009. Analysis of the Effect of Job Satisfaction and Motivation on Employee Performance with Organizational commitment as an Intervening Variable of PT. Semeru Karya Buana Semarang. (TA no.C4A006439 / MM / 2009). Unpublished Thesis of Diponegoro University, Semarang. Retreived March 25, 2013 from http://eprins.undip.ac.id/17249/

Dharma, Agus, 2004, Management Supervision, Raja Grafindo Persada, Jakarta

Ernawati and Ambarini, 2010, "The Effect of Work Relationship and Work Environment on Employee Performance with Motivation as a Moderating Variable". Journal of Economics and Entrepreneurship.

Flippo, Edwin B. 2007. Personnel Management Sixth Edition. Raja Grafindo. Jakarta.

Gathungu, Edith, Mike Iravo, Namusonge, 2015, Transformational Leadership and Employee's Commitment: Empirical Review. Journal of Asia Business Studies

Gibson et al. L. James, Donelly Jr. H. James and Ivansevich M. John, 2001, Fundamental of Management, Eight, Richard D. Irwin Inc., New York. 
International Journal of Economics, Business and Accounting Research (IJEBAR)

Peer Reviewed - International Journal

Vol-4, Issue-2, 2020 (IJEBAR)

E-ISSN: 2614-1280 P-ISSN 2622-4771

https://jurnal.stie-aas.ac.id/index.php/IJEBAR

Gomes, Faustino Cardoso, 2003. Human Resource Management, Andi Offset Publisher, Yogyakarta.

Hadiwiryo, Siswanto Sastro, 2003, Management of Indonesian Workers Administrative and Operational Approaches, Second Catakan, Jakarta: Bumi Aksara.

Harwiki, Wiwiek. 2013. Influence of Servant Leadership to Motivation, Organization Culture, Organizational Citizenship Behavior (OCB), and Employee's Performance in Outstanding Cooperatives in East Java Province, Indonesia. IOSR Journal of Business and Management (IOSR-JBM) e-ISSN: 2278-487X. Volume 8, Issue 5 (Mar. - Apr. 2013), PP 50-58

Hatta, Muhammad. 2011. Thesis "Analysis of Factors That Influence the Quality of Services to the Community Through Employees of the Berau Regency Integrated Licensing Service Board (BPPT)". Masters in Management. Mulawarman University.

Hurduzeu, Raluca-Elena, 2015, The Impact of Leadership On Organizational Performance SEA - Practical Application of Science, 2015, issue 7, 289-294

Ilyas, Yaslis, 2009. Theory of Assessment and Research, FKUI, Jakarta.

Judanto, Tunggul. 2002. Analysis of the Effect of Work Ability and Motivation Factors on Employee Performance (Case Study at Bank Danamon Semarang Youth) TESIS Dipenegoro University.

Kouzes, J.M. \& Posner, B.Z. 2007.The Leadership Challenge. 4th Eds. John Wiley and Sons.

Kuntjoro, S. 2002. Human Resource Management. Jakarta. CV Rajawali Pers. Jakarta.

Llyod. Byer, and Lislie W. Rue 2009. Management Skills and Apply Applications, Richard D, Irwin.

Luthans, Fred. 2000. Organizational Behavior (Interpreting V. A Yuwono, et al). Indonesian edition. Yogyakarta: ANDI.

Maholtra, 2004, Research Methods, New Edition, Jakarta: Rineka Cipta

Martoyo, Susilo. 2008. Human Resource Management. BPFE, Yogyakarta.

Masri \& Effendi, 2004, 18th Printing Survey Survey Method, Revised Edition, Publisher of PT Pustaka LP3ES Indonesia, Jakarta.

Melmambessy, Dani, 2008, The influence of leadership on the performance of PT Merpati Nusantara operational employees at Jayapura sentani airport.

Meyer, et al. 2004, Chariacteristic and Goal Human Resources Management. Jhon Wiley \& Sons Inc.

Muhammad, Arni, 2002. Organizational Communication. PT Bumi Aksara. Jakarta.

Naile, Idah, Jacob M Selesho, 2014, The Role of Leadership in Employee Motivation, Mediterranean Journal of Social Sciences, MCSER Publishing, Rome-Italy, E-ISSN 2039-2117, ISSN 2039-9340, Vol 5 No 3, March 2014.

Nasir, Wiyono, Supriyono, Supriyanto, 2017. Influence Leadership, Motivation, Competence, Commitment To Satisfaction And Performance Lecturer At Private Higher Education Kopertis Region IX in South Sulawesi Province. IOSR Journal of Business and Management (IOSR-JBM) e-ISSN: 2278-487X, p-ISSN: 2319-7668. Volume 19, Issue 7. Ver. VII. (July 2017), PP 56-67

Nasution, M. N., 2001, Integrated Quality Management (Total Quality Management). Jakarta .: Ghalia Indonesia.

Noerhayati, Endah. 2011. Journal. Effect of Organizational Motivation and Commitment on Performance. Semarang State University

Noermijati, Irvan Trang, Armanu, Achmad Sudiro, 2013, Organizational Commitment as Mediation Variable Influence of Work Motivation, Leadership Style and Learning Organization to the Employees Performance. OSR Journal of Business and Management (IOSR-JBM) e-ISSN: 2278-487X. Volume 7, Issue 2 (Jan. - Feb. 2013), PP 12-25 www.iosrjournals.org 
International Journal of Economics, Business and Accounting Research (IJEBAR)

Peer Reviewed - International Journal

Vol-4, Issue-2, 2020 (IJEBAR)

E-ISSN: 2614-1280 P-ISSN 2622-4771

https://jurnal.stie-aas.ac.id/index.php/IJEBAR

Samarinda City Government Regulation. 2016. Regional Regulation Number 04 Year 2016. Regarding Formation and Arrangement of Regional Apparatus.

Priyatno, Dwi. 2009. Mandiri Learning SPSS. Yogyakarta. MediaKom.

Purnomowati, Endang, 2006. Analysis of the effect of motivation on employee performance and job satisfaction with the commitment moderator variable. TESIS Airlangga University. Surabaya.

Purwanto. Djoko, 2003, Business Communication, Second Edition of Erlangga Jakarta.

Putri, Natalia Dewinda, 2011, The Effect of Organizational Commitment and the Role of Regional Financial Management Managers on Managerial Performance of Regional Work Units. Diponegoro University, 2011, Semarang.

Rangkuty, Fredy. 2005. Marketing Research. Third Matter. Jakarta: PT. Gramedia General Library.

Republic of Indonesia. Government Regulation Number 18 Year 2016 Regarding Regional Apparatuses, Followed Up With Regional Regulations

Republic of Indonesia. Government Regulation Number 41 Year 2007 Concerning Regional Organization Organizations, Personnel Affairs

Riduwan, Akdon, 2006, Formulas and Data in Statistical Analysis, Andi Publishers, Yogyakarta.

Rivai, Veithzal. 2002. Leadership and Organizational Behavior, First edition, PT Raja Grafindo, Jakarta.

Robbins Stephen and Judge. 2008. Organizational Behavior. Tenth Edition. Prentice Hall, Upper Saddle River, New Jersey.

Robbins, Stephen P., 2001. Organizational Behavior, Concepts, Controversies, Applications. Volume I and II. Eighth edition, Jakarta, Prenhallindo.

Robbins, Stephen P., 2007. Organizational Behavior. Tenth Edition. Prentice Hall, Upper Saddle River, New Jersey.

Roslinawati, Yunia, 2011, The influence of leadership, organizational commitment and motivation on the performance of cooperative staff and UMKM in Central Java Province

Ruky, M Saiful. 2002. Assessing Participation in Companies. Index: Jakarta.

Runi, Ramli, Nujum, Kalla, 2017. The Relationship between Motivation, Organizational Commitment and Competence with Job Satisfaction and Performance Lecturers. International Journal of Learning and Development ISSN 2164-4063 2017, Vol. 7, No. 3

Sarundajang. 2002, Regional Governments in Various Countries, Sinar Harapan Library. Jakarta.

Satiadarma, Monty P. and Fidelis E. Waruwu, 2003, Educating Intelligence, First Edition, Torch Popular Library, Jakarta.

Schuler, Randall and Susan E. Jackson, 2009. Human Resources Management, West Publishing Company, New York.

Awarmayanti. 2010. Human Resource Management Bureaucratic Reform and Management of Civil Servants, PT. Refika Aditama, Bandung.

Singarimbun, Masri and Efendi. 1995. Human Resource Management. Yogyakarta. STIE.

Smat, Warsid. 2005. The influence of leadership style on employee motivation in Regional VI of the Medan Civil Service Agency (BKN). Postgraduate Program in Management Studies Program, University of North Sumatra.

Soeprihanto, J. 2010. Performance Appraisal and Employee assessment. BPFE: Jakarta.

Sopiah, 2008. Organizational Behavior. Yogyakarta. ANDI Yogyakarta.

Spiegel, Murray R, 2004, Statistics Second Edition, McGraw-Hill, Inc.

Sugiyono 2013. Statistics for Research. Bandung. Alfabeta. 
International Journal of Economics, Business and Accounting Research (IJEBAR)

Peer Reviewed - International Journal

Vol-4, Issue-2, 2020 (IJEBAR)

E-ISSN: 2614-1280 P-ISSN 2622-4771

https://jurnal.stie-aas.ac.id/index.php/IJEBAR

Sunyoto, Danang. 2012. Path Analysis Model for Economic Research. Bandung. Yrama Widya.

Terry. George R. 2009. Principle Of Management, Richard D. Irwin, Inc. Homewood, Illinois Irwin Dorsey Limited

Tistiningtiyas, Dwi, 2007, The effect of organizational commitment on employee performance (study of PD. BPR Bank Pasar Lamongan employees).

Tohardi, Ahmad, 2002. Practical Understanding of Human Resource Management, First Printing, Mandar Maju, Bandung.

Umar, Husein, 2009. Human Resources Research in Organizations, PT Gramedia Pustaka Utama, Bandung.

Wibowo. 2010. Performance Management. Raja Grafindo Persada. Jakarta.

Winardi, J. 2007. Leadership Management and Management. PT. Rineka Cipta, Jakarta.

Wiryawan. 2009. Evaluation of Human Resource Performance: Application Theory and Research. Salemba Empat. Jakarta.

Wood et al. 2001. Organizational behavior and Asia Pacific perspective. First edition. John Willey \& Sons. The USA.

Wursanto I.G. 2002. Staffing Management Volume 1. Kanisiu. Yogyakarta.

Yukl, Gary, 2001. Leadership in Organization. Fifth Edition. Prentice-Hall. Inc., Upper Saddle River, New Jersey. 